tutions to which UMI extended the offer. The Library plans to order complete sets of many titles now partially held as well as runs of some 250 new titles and additional viewing equipment.

-The University of Utah, Salt Lake City, has received a $\$ 41,340$ grant from the U.S. Department of Education to make its social sciences data files accessible to other institutions in the Interuniversity Consortium for Political and Social Research. Established in 1962, the ICPSR collection includes more than 1,300 tapes on topics ranging from elections to geographic mobility of workers. A code book describes the contents of each file. With the grant, Utah plans to purchase all ICPSR code books, collect existing OCLC catalog entries, identifying data files for which no catalog record exists and creating records for them.

\section{News note}

- Northern Illinois University, DeKalb, hosted six representatives of the Japan Library Association on October 12 as part of their natjonwide study tour. The Japanese librarians were in the United States as guests of the U.S. Information Agency in order to study advanced library computer network systems and services. The NIU visitors included Masaharu Itoga, from the School of Library and Information Science at Keio University; Hajime Mori, director of the Yamagata Prefectural Library; Hajime Nishio, chief of the Acquisition and Processing Section of the Tottori Prefectural Civic Library; Toshihiko Ogawa, deputy secretary general of the Japan Library Association; Akira Toda, chief of the Computer Planning Office at the Setagaya Ward Library in Tokyo; and Shinji Tomie, associate professor at Tsukuba University.

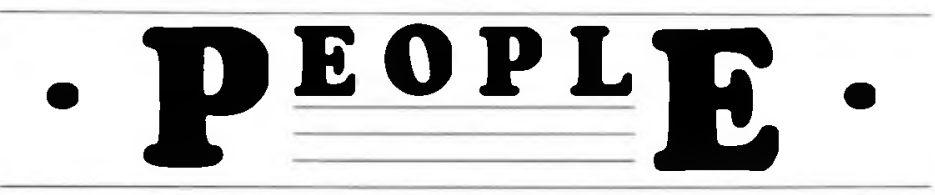

\section{Profiles}

Peter G. Watson, assistant university librarian at California State University, Chico, since 1985 , has been named university librarian at Idaho State University, Pocatello.

Watson, a native of Oldham, England, received his MLS with distinction from the University of California, Los Angeles, in 1969. His undergraduate work was done in English and philosophy at the University of Manchester, and he holds a master's degree in English from the University of California, Santa Barbara.

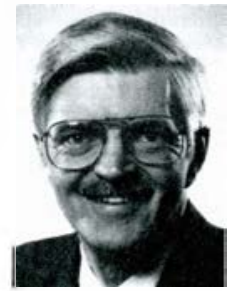

Peter G. Watson
Watson worked at the

UCLA Library from 1969 to 1976 , when he joined the Meriam Library at California State University, Chico, as reference librarian and data services coordinator. In 1984 he was named head of the Access Services Division, and one year later was named assistant university librarian for programs and services.

A member of the Idaho Library Association and ALA, Watson has been active in ACRL, LAMA,
LITA, LRRT, RTSD, and RASD, where he currently chairs the Steering Committee of the Collection Development and Evaluation Section. He has to his credit 16 monographs, 34 articles, and 16 book reviews.

Charles Palm, head librarian and archivist at Stanford University's Hoover Institution, has been appointed associate director of the Hoover Institution. He succeeds John B. Dunlop, who will devote his time to research and writing.

A graduate of Stanford University, Palm was appointed archivist in 1984 and head librarian in 1986 , and has been a member of the Institution staff since 1971. He holds graduate degrees in history and library science from the University of Wyoming

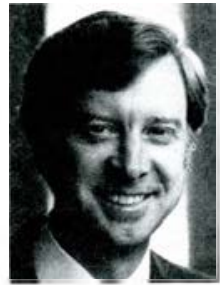

Charles Palm and the University of

Oregon. He was an archivist intern at the U.S. National Archives from 1970 to 1971.

Palm has played a leading role in both national and state professional associations. A past president of the Society of California Archivists (SAA), he has 
served as chairman of the Society of American Archivists Committee on Goals and Priorities and as chairman of its Awards Committee. As a member of the SAA Task Force on National Information Systems, he helped set national bibliographic and format standards for archival information.

Palm is co-author of the Guide to the Hoover Institution Archives and Herbert Hoover: A Register of His Papers at the Hoover Institution.

\section{People in the news}

BRENDa Barlfy, public services librarian at Fort Lewis College, Durango, Colorado, has been selected to serve as editor of Colorado Libraries beginning in January. Colorado Libraries is a quarterly journal published by the Colorado Library Association that features articles of interest to librarians throughout the United States.

Richard D. Johnson, director of libraries at State University College, Oneonta, New York, is serving as the college's loaned executive to the United Way of Greater Oneonta during Fall Semester 1987.

Pat Molholt, associate director of libraries at Rensselaer Polytechnic Institute, has taken a sabbatical leave to spend five months working with Anne Mathews, director of the U.S. Department of Education's Office of Library Programs. Molholt will work with the National Science Foundation, EDUCOM, regional networks, and state library personnel on the role of libraries in regional and national network environments, especially with regard to issues of standards, governance, and access.

\section{Appointments}

(Appointments are taken from library newsletters, letters from personnel offices and appointees, and other sources. To ensure that your appointment appears, write to the Editor, ACRL, $50 \mathrm{E}$. Huron St., Chicago, IL 60611-2795.)

SuSAN M. Agent has been appointed retrospective conversion librarian in the Bibliographic Control Department at the University of Delaware, Newark.

Barbara Alexander has been appointed humanities reference librarian at Texas A\&M University, College Station.

Frances OTt ALLEN is the new German cataloger at the University of Cincinnati, Ohio.

Patti Ashby has joined the serials staff in the Science Library at Bowling Green State University, Ohio.

JUDY AvERY is the new head of the Reference Service Department in the Graduate Library at the University of Michigan, Ann Arbor.

CAROLYN BABFr has been appointed humanities reference librarian in the General Reference Division at San Diego State University, California.

LEETA BAILEY has been appointed interlibrary loan/assistant reference librarian at Amberst College, Massachusetts.

Deborah Barlow has been appointed art librarian at Queens College, Flushing, New York.

ANN BEKINs has been appointed serials catalog librarian at Brown University, Providence, Rhode Island.

CANDACF BENEFIEI has been appointed humanities reference librarian at Texas A\&M University, College Station.

SIDNEY E. BERGER is the new curator of printed books at the American Antiquarian Society, Worcester, Massachusetts.

Moliy S. Bernaro has been appointed information services librarian in the Health Sciences Library and Information Center at the University of Washington, Seattle.

Gary Bentchume has been promoted to bibliographic analyst in the Library Systems Office at Columbia University, New York City.

SHIRLEY A. BIGNA is the new assistant director of the library at the University of Indianapolis, Indiana.

Hsi-Chu Huang Bolick has been appointed catalog librarian at Wabash College, Crawfordsville, Indiana.

LAURA BOYER has been appointed reference librarian at California State University-Stanislaus, Turlock.

Alice BRENDEL has been appointed shared resources coordinator at Brown University, Providence, Rhode Island.

BRUCE BRINKLEY is now reference librarian at Wabash College, Crawfordsville, Indiana.

LISA BROWAR has been appointed assistant director for rare books and manuscripts at the New York Public Library, Manhattan.

J. Michael Bruer has been appointed associate director for preparation services at the Research Libraries, New York Public Library.

NANCY BuTkovich is now science reference librarian at Texas A\&M University, College Station.

LiNDA BEAUPRE CAIN has been named university librarian at the University of Cincinnati, Ohio.

Jo CALK is now authorities librarian in the Catalog Management Department at Cornell University, Ithaca, New York.

Robert Carande has been appointed science reference librarian in the Science Division at San Diego State University, California.

Sherry J. Carrillo is the new assistant director for reader services at Florida International University, Miami

Susan Case has joined the staff of the Clendenning History of Medicine Library at the University of Kansas Medical Center, Kansas City.

Susan Charles has been appointed science and technology reference librarian at Texas A\&M University, College Station.

Micheie Cloonan has been appointed preservation librarian at Brown University.

Catherine L. Crohan has been appointed seri- 
als librarian at Siena College, Loudonville, New York

Tony Cucchiara is now archivist and head of special collections at Brooklyn College, New York.

Loki N. CurTis has been appointed assistant curator of special collections at the University of Tulsa, Oklahoma

KATHY DARCY has been named director of the library at Donnelly College, Kansas City, Kansas.

Patrick Dawson is now cataloger at the University of California, Riverside.

Miniam Deutch has been appointed substitute access services librarian at Brooklyn College, New York

Diane DiMantino has been appointed reference librarian at Baruch College, New York City.

ANN MORGAN DODGE has been appointed conservator of library materials at Brown University, Providence, Rhode Island.

Patricia A. FitzGerald is now assistant director for public services at Carnegie-Mellon University, Pittsburgh, Pennsylvania.

Charlotte B. Ford is now government documents librarian at the North Miami Campus of Florida International University.

DENise Fox has been appointed substitute serials/reference librarian at LaGuardia Community College, Long Island City, New York.

SALLY ANN FRY has been appointed information services librarian at Iowa State University, Ames.

Monica Fusich has been appointed bibliographic instruction coordinator and reference librarian at the University of California, Riverside.

Jony Gomrz is now monographs cataloger at Texas A\&M University, College Station.

Suzanne Griffiths is now assistant director of departmental library services for humanities libraries at the University of Illinois, UrbanaChampaign.

Euaine Griner is now technical services/serials control ljbrarian at Brenau College, Gainesville, Georgia

Christine H. Guyonneau has been appointed reference librarian/head of circulation and interlibrary loan at the University of Indianapolis, Indiana.

JOHN HAAR has been appointed head of collection management at Virginia Commonwealth University, Richmond.

GoRDON HENDRICKSON is the new Iowa State Archivist at the State Historical Society of Iowa, Inwa City.

Kate HenzoG is the new head of the Engineering and Mathematical Sciences Library at the University of California, Los Angeles.

Gretchen Holten has joined the staff of the Central Reference Services Department at the University of Nebraska, Lincoln.

MichaEL JoHnson has been appointed assistant to the director for library systems at Brooklyn College, New York.

NANCY RUCKER JoHnson is now special programs librarian at the Houston Academy of Medicine, Texas.

KAY JonEs has been appointed assistant univer sity librarian for administration at California State University, Sacramento.

JoAnna Katsune has been appointed catalog librarian at Brown University, Providence, Rhode Island.

IINDA J. KIMSEY is the new assistant catalog librarian at West Texas State University, Canyon.

JACKIE SUE KINDER is now assistant reference librarian at the University of South Carolina, Columbia.

JENNIFER Kolms is the new music cataloger in the Sound Recording Archives at Bowling Green State University, Ohio.

FLORENCE LANDON has been appointed associate librarian for administrative services at George Mason University, Fairfax, Virginia.

ROMAN LEGEDZa has been appointed to the Cataloging Department at the University of Nebraska, Lincoln.

LINDA LEGER has been appointed coordinator of user education at the University of Waterloo, Ontario.

Lisa Livincston is now chief of the AudioVisual Division at City College, City University of New York, Manhattan.

SEAN P. Maloney has been appointed interlibrary loan Librarian at Siena College, Loudonville, New York.

JONATHAN MaRnER has been appointed cataloger for the Goldsmiths'-Kress microfilm project at Texas A\&M University, College Station.

SUSAN MaRTIN has been appointed education reference librarian at Texas A\&M University, College Station.

Paul Mastrangelo has been appointed technical services coordinator at the New York Law School, New York City.

Lawrence Maxted is now head of the Periodicals Department at Gannon University, Erie, Pennsylvania.

Pamela D. Morgan has been appointed serials librarian at Old Dominion University, Norfolk, Virginia

Charles Owusu has been appointed evening/weekend reference librarian at LaGuardia Community College, Long Island City, New York.

Bernatdine Pachta is now circulation and reserves librarian in the Lamont Library of Harvard University, Cambridge, Massachusetts.

Donald PaDy has been appointed history of medicine librarian at the Mayo Foundation, Rochester, Minnesota.

SALLY Patrick has been named director of the library at the Peabody Institute, Danvers, Massachusetts.

Richard T. Paustenbaugh has been appointed assistant librarian for reference in the Business SPEA Library at Indiana University, 
Bloomington.

Martha N. Payne has been appointed coordinator of technical services and automation at $\mathbf{H a v e r -}$ ford College, Pennsylvania.

Laurie A. Potter has been named public services and science reference librarian at Le Moyne College, Syracuse, New York.

Mary Franklin Johnson Raisch has been appointed lawyer/librarian at the New York Law School, New York City.

Honora Raphael is now music librarian at Brooklyn College, New York.

ALICE RHOADFs has been appointed reclassification cataloger at Amherst College, Massachusetts.

Katherine RoBIE is now cataloger at Amherst College, Massachusetts.

Charlotte Ross is now Texas state documents librarian at Texas A\&M University, College Station.

Tracy C. Russell has been appointed information services librarian at Iowa State University, Ames.

ANN Schaffner has been appointed assistant director of the Science Library at Brandeis University, Waltham, Massachusetts.

Cecilia Schmitz has been appointed microforms cataloger at Texas A\&M University, College Station.

Martin Max Schreiner is now head of the Morse Music Library in the Hilles Library at Harvard University, Cambridge, Massachusetts.

JEAN SHADY has been appointed serials project librarian in the Law School Library of Harvard University, Cambridge, Massachusetts.

Linda S. Shaw has been appointed head of the Cataloging Department at the University of Indianapolis, Indiana.

Bradley Short has been appointed assistant creative arts librarian at Brandeis University, Waltham, Massachusetts.

SANDHa SHHOPSHIRE has been appointed catalog librarian at Idaho State University, Pocatello.

ALthea M. Silvera has been appointed university archivist and head of special collections at the University Park Campus of Florida International University, Miami.

Robert STRauss has been named executive director of the Conservation Center for Art and Historic Artifacts, Philadelphia, Pennsylvania.

JEAN-JACQUES STRAYER has been appointed interlibrary loan librarian at Hunter College, New York City.

Gwo-Hwa NanCY Sun has been appointed cataloger/systems coordinator at the North Miami Campus of Florida International University.

Vitus Tanc has been appointed head of the Copy Cataloging Section at Stanford University, California.

Lorelei TanjI has been appointed reference $\mathrm{li}$ brarian at the University of California, Riverside.

Canol M. Toniv has been appointed head of the Reference Department at the University of South
Carolina, Columbia.

Sandra TuCKen has been appointed social sciences reference librarian at Texas A\&M University, College Station.

MaRY ANNE UITTo has been appointed humanities reference librarian at the University of Delaware, Newark.

MrChaEL WALKER has been appointed reference librarian for university library services at Virginia Commonwealth University, Richmond.

Signid N. Wells has been appointed reference librarian for social sciences at Old Dominion University, Norfolk, Virginia.

Debonah West has been appointed gift books librarian at Gannon University, Erie, Pennsylvania .

Craic A. Wilson is the new assistant director of libraries for collection development at Oregon State University, Corvallis.

Christina Woo has been appointed head of the General Reference Division at San Diego State University, California

ROBERT WOLVEN is now assistant director of bibliographic control at Columbia University Law Library, New York City.

JoEL ZUCKEr has been appointed government documents/reference librarian at Bowling Green State University, Ohio.

\section{Retirements}

JEAnNe Briner, acquisitions librarian at the University of Arizona, will retire in February 1988. Briner completed her MLS at Columbia University and then worked for New York University and the American Museum of Natural History. She first worked at the University of Arizona in the early 1960 s when she came to Tucson to pursue graduate studies, and worked as head catalog librarian at Wittenberg University in 1966-1967 before assuming her present position at Arizona.

Mary AnNa Krause retired in September after 26 years of service in the Harvard Law School Library. She first held the title of acquisitions librarian, then from 1981, was selector for AngloAnerican law. She was an active member of professional law librarian associations and served on the University Library's Communications and Orientation Committee.

Robert J. STARring, head of the Department of Rare Books and Special Collections at the University of Michigan since 1984, has retired after more than 20 years of service. Starring has held a variety of administrative posts at the University of Michigan: head of book purchasing and receiving (1967-1969), assistant head of circulation at the Graduate Library (1969-1972), assistant head of the Graduate Library (1972-1975), acting head of the Graduate Library (1975-1976), assistant to the associate director for public services (1976-1981), and coordinator of the Social Sciences and Humanities Libraries (1981-1984). Before coming to 


\section{MIDWEST LBRARY}

\section{SERVICE}

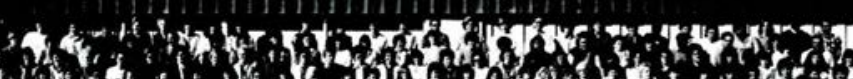

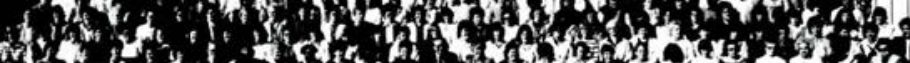

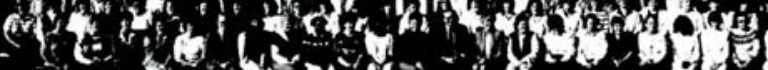

\section{$-$ ,

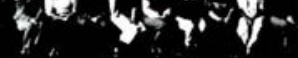 \\ MLS-160 People Dedicated to Providing Service to Libraries}

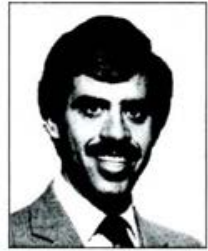

Jay Askuvich General Sales Manager

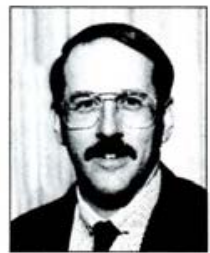

Scott Schmidt Midwest

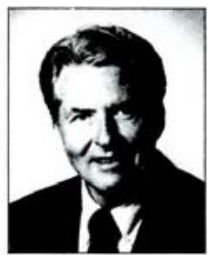

Carl Dorr Southeast

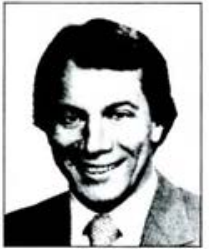

Lawrence Nagel West

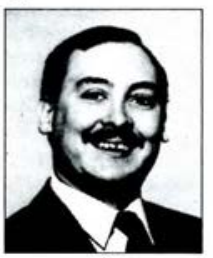

Forrest Link Northeast

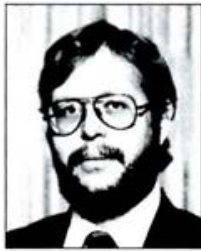

Kim Anderson Mountain Plains

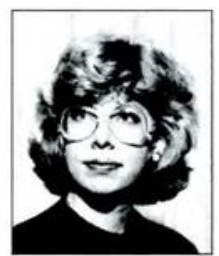

Lorraine Best Canada

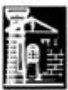

Midwest Library Service

11443 St. Charles Rock Road

Bridgeton, MO 63044, USA

Call toll-free 1-800-325-8833

Missouri librarians call toll-free 1-800-392-5024

Canadian librarians call toll-free 1-800-527-1659 
Michigan, Starring was district manager for Doubleday Book Shops in the Detroit area.

ElizabeTh Thompson, non-print materials specialist at the University of the District of Columbia, retired at the end of September. A graduate of Douglass College with an MLS from the Catholic University of America, she had been on the UDC library and media staff for 16 years. Thompson joined the staff as a librarian at the D.C. Teachers College in 1971 and moved into the Media Services Department of the University's Learning Resources system in 1978 .

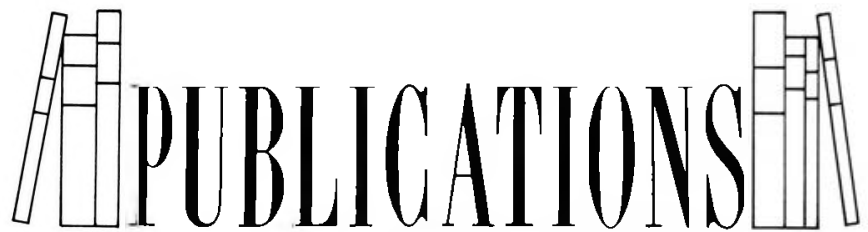

- The Academic Library Director: Management Activities and Effectiveness, by Joanne R. Euster (168 pages, November 1987), analyzes the contribution of the director's personal leadership style and management skills to the successful operation of a college, university, or research library. Euster develops a model of the leadership role that takes account of management literature regarding organizational leadership, open systems theories, and organizational effectiveness. Proposing a typology of library leaders, she presents detailed profiles of four primary leadership types-the "Energizer," the "Sustainer," the "Politician," and the "Retiree." Appendices contain study questionnaires and methodological notes. A copy may be ordered for $\$ 35$ from Greenwood Press, 88 Post Road West, Box 5007, Westport, CT 06881. ISBN 0-31325789-2.

- The third annual Automation Inventory of Research Libraries (160 pages, October 1987) has been published by the Association of Research Libraries' Systems and Procedures Exchange Center. The inventory explores 18 automated functions according to six descriptive elements: operating status (planned, operating or modifying), extent of system (library only, branches, campus-wide, or multi-institution), computer ownership/use (dedicated or shared), public access (onsite, dial-up or local area network), number of workstations, and name of vendor or network. The 18 functions covered this year are: acquisitions, serials cheek/claim, serials/union list, authority control, cataloging/utility, cataloging/local, circulation, reserve room, COM catalog, online catalog, database

\section{Deaths}

Howard W. Cokdeld, former director of libraries at Florida International University, died on October 21 in Gainesville.

Hans Moldenhauer, honorary curator of 20thcentury music in the Harvard College Library since 1984, died at his home in Spokane, Washington, the week of October 19th. Moldenhauer was the founder and director of the Moldenhaner Archives, a collection of primary musical sources from the Renaissance to the present. In addition to his achievements as a collector, he was noted as a concert pianist, teacher, author, and lecturer. searching, collection development, interlibrary loan, telefacsimile, public computing, administrative, database conversion, and reference. Narrative comments from 58 of the 115 ARL libraries surveyed are included. Copies may be ordered for $\$ 40$ (prepaid) from SPEC, OMS/ARL, 1527 New Hampshire Ave., N.W., Washington, DC 20036.

- A Bibliography of Latin American and Caribbean Bibliographies, 1986-1987, by Lionel V. Lorona (64 pages, October 1987), has been published as number 20 in the SALALM Bibliography and Reference Series. This fifth annual edition covers relevant monographic and periodical bibliographies in all topics from agriculture to urbanization. Copies are available for $\$ 13$ (plus $\$ 2$ shipping) from the SALALM Secretariat, 728 State Street, Madison, WI 53706.

-A Check-list of Publications of H.H. Bancroft and Company, 1857 to 1870 , by Henry $\mathrm{R}$ Wagner, Eleanor Bancroft, and Ruth Frey Axe (52 pages, October 1987), documents the output of the publishing company founded by Hubert Howe Bancroft (1832-1918), collector of Western and Latin Americana and the founder of the Bancroft Library. During its 14-year existence, Bancroft's company issued 212 titles. Henry Wagner's checklist of Bancroft publications was left unfinished at his death in 1957, and his collaborator, Eleanor Ashby Bancroft, then assistant to the director of the Bancroft Library, also died in that year. Wagner's long-time associate, Ruth Frey Axe, has now completed the work, which has been published jointly by the Friends of The Bancroft Library and the Friends of the UCLA Library. A copy may be or 